\title{
In-vitro Characteristics Comparison of Prepared Immediate Release Tablet of Linagliptin with Innovator Drug and Selected Market Samples of Bangladesh
}

\author{
Shafiqul Islam Sovon ${ }^{1}$, Habibullah ${ }^{1}$, Hafizur Rahman ${ }^{2}$ and Tushar Saha*2 \\ ${ }^{1}$ Prodcut Development Department, ACI Pharmaceuticals Ltd, Bangladesh \\ ${ }^{2}$ Research and Development Department, Square Pharmaceuticals Ltd, Bangladesh \\ Submission: October 18, 2018; Published: November 13, 2018 \\ *Corresponding author: Tushar Saha, Research and Development Department, Square Pharmaceuticals Ltd., Bangladesh
}

\section{Abstract}

The aim of the current investigation is to prepare immediate release tablet of Linagliptin and then compare its characteristics with innovator drug and marketed samples of Bangladesh. Direct compression technique was applied to prepare immediate release tablet of Linagliptin and physical characteristics as well as In-vitro dissolution study was performed.Characteristics of prepared tablet, innovator drug and marketed samples all were in official limit. Prepared Linagliptin tablet had better immediate release profile than innovator drug and marketed samples.

Keywords: Linagliptin;Immediate release;Innovator drug;Marketed samples

\section{Introduction}

Diabetes Mellitus is a chronic and incurable disorder which affects a large number of populations and it is in increasing trend[1]. If it is not managed properly than it will cause clinical, social and economic complications. Diabetic patient has to live with this disease and thus has to take medication during whole life which eventually causes a large amount of cost in drug therapy. Linagliptin is an effective agent which lowers blood glucose level. It is widely used to treat type- 2 diabetes and recommended to take once daily[2]. In the meantime, oral route is considered as the most convenient route of medication and getting action in a quickest possible time is one of the main objectives of any medication. Basis on this, an attempt was made to prepare immediate release tablet of Linagliptin and compare its characteristics with innovator drug and marketed samples of the country so that an idea can generate about the quality of prepared tablet.

\section{Materials}

Materials used in this experiment were of analytical gradeand purchased from local market. Two marketed samples were collected from retail pharmacies of Dhaka city, Bangladesh. Expiry date was checked before collecting marketed samplesso as to ensure that those samples are valid and can be used. Tablets of marketed samples were purchased of same batch number.

\section{Methods}

\section{Coding}

Prepared tablets were coded as L-1, L-2 and L-3, innovator drug was coded as I and marketed samples were coded as M-1 and $\mathrm{M}-2$.

\section{Preparation of immediate release Linagliptin tablet}

At first, drug and other excipients were weighed according to the formula (Table 1) and then blended. After proper blending and mixing direct compression technique was applied to prepare the tablet[3-5].

Table 1: Composition of Immediate Release Tablet of Linagliptin.

\begin{tabular}{|c|c|c|c|c|c|}
\hline Code & $\begin{array}{c}\text { Linagliptin } \\
\text { (mg) }\end{array}$ & $\begin{array}{c}\text { SSG } \\
\text { (mg) }\end{array}$ & $\begin{array}{c}\text { Lactose } \\
\text { (mg) }\end{array}$ & $\begin{array}{c}\text { Magnesium } \\
\text { Stearate } \\
\text { (mg) }\end{array}$ & $\begin{array}{c}\text { Total weight } \\
\text { (mg) }\end{array}$ \\
\hline L-1 & 5 & 10 & 183 & 2 & 200 \\
\hline L-2 & 5 & 15 & 178 & 2 & 200 \\
\hline L-3 & 5 & 20 & 173 & 2 & 200 \\
\hline
\end{tabular}




\section{Evaluation of physical properties of tablet}

Existing official methods were followed in-order to find out the characteristics of prepared tablet as well as the innovator drug and marketed samples.

\section{In-vitro dissolution study}

In-vitro dissolution study was performed by taking tablets in dissolution media which was $900 \mathrm{ml}$ of $0 . \mathrm{N} \mathrm{HCl}(\mathrm{pH} \mathrm{1.2)} \mathrm{solution.}$ Temperature was set $37 \pm 0.5^{\circ} \mathrm{Cand}$ rpm was $50.5 \mathrm{ml}$ of solution was taken in a definite time period for analysis and fresh solution was transferred into the media. Withdrawn solution of samples was analyzed at $299 \mathrm{~nm}$ by using UV-visible spectrophotometer.

\section{Results and Discussion}

\section{Physical properties of tablet}

Physical parameters of prepared tablets, innovator drug and marketed samples were performed which results are tabulated inTable 2. It was found that, all were in the specification of official limit.

Table 2: Physical parameters of prepared tablets, innovator drug and marketed samples were performed which results are tabulated in this table.

\begin{tabular}{|c|c|c|c|c|c|}
\hline Code & Average weight (mg) & Weight variation (\%) & Hardness (kg/cm $\mathbf{~})$ & Disintegration time (min) & Assay (\%) \\
\hline I & 180.89 & 1.64 & 4.49 & 3.17 & 101.95 \\
\hline L-1 & 200.14 & 1.2 & 3.54 & 1.78 & 100.11 \\
\hline L-2 & 199.96 & 1.54 & 3.31 & 1.65 & 99.64 \\
\hline L-3 & 200.04 & 1.15 & 3.64 & 1.49 & 100.78 \\
\hline M-1 & 194.02 & 0.98 & 5.23 & 3.69 & 101.04 \\
\hline M-2 & 102.91 & 2.76 & 4.1 & 2.52 & 99.87 \\
\hline
\end{tabular}

\section{In-vitro dissolution study}

In-vitro dissolution result of prepared tablet, innovator drug and marketed samples are presented in Table 3.

Table 3: Dissolution profile of Innovator Drug (I), Prepared Tablets (L-1, $\mathrm{L}-2, \mathrm{~L}-3)$ and Marketed Samples(M-1 and M-2).

\begin{tabular}{|c|c|c|c|c|}
\hline Code & $\mathbf{1 0 m i n}$ & $\mathbf{2 0 m i n}$ & $\mathbf{3 0 m i n}$ & $\mathbf{4 5 m i n}$ \\
\hline I & $48.98 \%$ & $92.10 \%$ & $101.99 \%$ & $106.71 \%$ \\
\hline L-1 & $87.21 \%$ & $97.96 \%$ & $100.66 \%$ & $102.01 \%$ \\
\hline L-2 & $95.13 \%$ & $101.03 \%$ & $102.54 \%$ & $104.15 \%$ \\
\hline L-3 & $94.97 \%$ & $100.21 \%$ & $103.09 \%$ & $104.02 \%$ \\
\hline M-1 & $86.11 \%$ & $97.43 \%$ & $102.01 \%$ & $103.98 \%$ \\
\hline M-2 & $74.77 \%$ & $91.73 \%$ & $96.91 \%$ & $103.81 \%$ \\
\hline
\end{tabular}

From Table-2, it is clear that, prepared Linagliptin tablets (L$1, \mathrm{~L}-2$ and L-3) have better release profile than the innovators and marketed samples. $100 \%$ drug release was achieved first by prepared tablets. L- 1 achieved it in 30 min and both L-2 and L-3 achieved it in $20 \mathrm{~min}$. whereas, in case of marketed and innovator sample, all took minimum $30 \mathrm{~min}$ to release $100 \%$ of drug.

\section{Conclusion}

Immediate release tablet of Linagliptin was formulated and compare with the innovator drug and marketed samples successfully in the present study. It was also found that, quality of the marketed samples were also up to the mark as their obtained result were satisfactory. Commercialization of the investigated immediate release tablets of Linagliptin will positively impact our society as the number of diabetic patients is increasing day by day.

\section{References}

1. Saha $T$ (2018) Preparation and evaluation of immediate release gliclazide tablet using super disintegrants. IJP 5(5): 294-297.

2. Forst T, Pfutzner A (2012) Linagliptin, a dipeptidyl peptidase-4 inhibitor with a unique pharmacological profile, and efficacy in a broad range of patients with type 2 diabetes. Expert OpinPharmacother 13(1): 101-110.

3. Bithi FA, Saha T, Ahmed NA, Hasan IH, Reza MS (2017) Preparation and in vitro evaluation of mucoadhesive tablets of montelukast sodium. Bangladesh Pharmaceutical Journal 20(2): 123-131.

4. Saha P, Das PS, Saha T, Jahan I, Chegini Z (2018) Preparation and Characterization of Gastroretentive Floating Tablets of Ondansetron HCl. AAPSJ 2(2): 26-30.

5. Saha T, Masum ZU, Ashrafi S (2018) Preparation and In-Vitro Evaluation of Sodium Alginate Based Gastroretentive Floating Tablet of Domperidone. Galore International Journal of Health Sciences \& Research 3(1):1-4. 
(C) (1) Commons Attribution 4.0 License BY DOI: 10.19080/JCMAH.2018.08.555741

\section{Your next submission with Juniper Publishers will reach you the below assets}

- Quality Editorial service

- Swift Peer Review

- Reprints availability

- E-prints Service

- Manuscript Podcast for convenient understanding

- Global attainment for your research

- Manuscript accessibility in different formats ( Pdf, E-pub, Full Text, Audio)

- Unceasing customer service

Track the below URL for one-step submission https://juniperpublishers.com/online-submission.php 